УДК:378.22:1:001.891

DOI $10.25128 / 2415-3605.20 .1 .18$

\title{
ВІКТОРІЯ МЕНЯЙЛО
}

ID ORCID: 0000-0003-1926-5984 meniailo16@gmail.com

кандидат фізико-математичних наук, доцент

Запорізький національний університет вул. Жуковського, 66, м. Запоріжжя

\section{КОНЦЕПТУАЛЬНА МОДЕЛЬ ПІДГОТОВКИ МАЙБУТНІХ ДОКТОРІВ ФІЛОСОФІЇ ДО ДОСЛІДНИЦЬКО-ІННОВАЦІЙНОї ДІЯЛЬНОСТІ}

\begin{abstract}
Представлено конщептуальну модель підготовки майбутнього доктора філософії до дослідницько-інноваційної діяльності. Актуальність иієї теми пов'язана із становленням і розвитком третього рівня вищої освіти в Україні, щчо потребує вивчення зарубіжного досвіду та імплементації його у практику. Запропонована модель складається із п'яти блоків. У иільовому блочі зазначаються мета дослідження, нормативні та методологічні засади процесу підготовки майбутніх докторів філософії. Змістовий блок розкриває зміст підготовки аспірантів до дослідницько-інноваційної діяльності, сформований на підставі аналізу сучасних вимог до науково-педагогічних працівників та побудованого профілю доктора філософії, щчо відображено в освітньо-наукових програмах, навчальних планах та індивідуальних планах роботи аспірантів. В організаційному блоиі наведено структуру, завдання $i$ функиії інноваційного освітньо-наукового середовищза університету. В операційному блоці описано двокомпонентну систему підготовки докторів філософії, де освітній компонент рядом 3 традииійно-організованим навчанням включає проєктно-організоване та додаткове навчання поза навчальним прочесом, а науковий компонент, окрім обов'язкової роботи над дисертаційним дослідженням передбачає інші форми і методи дослідницько-інновачійної діяльності в університеті як складової квазіпрофесійної діяльності майбутніх докторів філософії, а також містить заходи $з$ професійного розвитку молодих науковиів. У діагностичному блоиі наведено критеріі, показники та рівні готовності майбутнього доктора філософії до дослідницько-інноваційної діяльності, зазначаються методи та інструменти їх визначення.
\end{abstract}

Ключові слова: доктор філософії, дослідницько-інноваційна діяльність, концептуальна модель, аспірант, професійна підготовка, вища освіта

\section{ВИКТОРИЯ МЕНЯЙЛО}

кандидат физико-математических наук, доцент Запорожский национальный университет ул. Жуковского, 66, г. Запорожье

\section{КОНЦЕПТУАЛЬНАЯ МОДЕЛЬ ПОДГОТОВКИ БУДУЩИХ ДОКТОРОВ ФИЛОСОФИИ К ИССЛЕДОВАТЕЛЬСКО-ИННОВАЦИОННОЙ ДЕЯТЕЛЬНОСТИ}

\begin{abstract}
Представлена концептуальная модель подготовки будущего доктора философии к исследовательско-инновационной деятельности. Актуальность данной темы связана со становлением и развитием третьего уровня высшего образования в Украине, что требует изучения зарубежного опыта и имплементации его в практику отечественных вузов. Предложенная модель состоит из пяти блоков. В иелевом блоке указывается ичель исследования, нормативные и методологические основы прочесса подготовки будущих докторов философии. Содержательный блок раскрывает содержание подготовки аспирантов к исследовательско-инновачионной деятельности, сформированное на основании анализа современных требований к научно-педагогическим работникам и построенного профиля доктора философии, что нашло свое отражение в образовательно-научных программах, учебных планах и индивидуальных планах работы аспирантов. В организационном блоке приведена структура, задачи и функиии инноваџионной научно-образовательной среды университета. В операџионном блоке описано двухкомпонентную систему подготовки докторов философии, где образовательньй компонент наряду с традиционно организованным обучением включает и проектно-организованное, и дополнительное обучение вне учебного прочесса, а научный компонент, кроме обязательной работь над диссертационным исследованием, предусматривает другие формь и методь исследовательско-
\end{abstract}


инновационной деятельности в университете как составляющей квазипрофессиональной деятельности будущих докторов философии, а также содержит меры по профессиональному развитию молодых ученых. В диагностическом блоке приведень критерии, показатели и уровни готовности будущего доктора философии к исследовательско-инноваџионной деятельности, указываются методь и инструменты их определения.

Ключевье слова: доктор философии, исследовательско-инновачионная деятельность, концептуальная модель, аспирант, профессиональная подготовка, высшее образование.

\section{VIKTORIIA MENIAILO}

$\mathrm{PhD}$ in Physics and Mathematics, Assistant professor Zaporizhzhia National University 66 Zhukovskogo Str., Zaporizhzhia

\section{THE CONCEPTUAL MODEL OF TRAINING OF FUTURE DOCTORS OF PHILOSOPHY FOR THE RESEARCH AND INNOVATION ACTIVITY}

The article presents a conceptual model of training of a future doctor of pilosophy for the research and innovation activity. The relevance of the problem is related to the establishment and development of the third level of higher education in Ukraine, which requires the study of foreign experience and its implementation in the practice of domestic higher education institutions. The proposed model consists of five blocks (the target, informative, organizational, operational and diagnostic) and reflects the three steps of this process. At the theoretical and methodological stage represented in the target block, there have been determined the purpose of the research, normative and methodological frameworks for the process of training a future doctor of philosophy. The substantive-practical stage is featured by the informative, organizational and operational blocks of the model. The informative block reveals the content of the training of postgraduate students for the research and innovation activity, which is formed on the basis of the analysis of modern requirements for scientificpedagogical employees and the constructed profile of a Ph.D., which has been reflected in educational-scientific programs, curricula and individual work plan of a postgraduate student. The organizational block describes the structure, tasks and functions of the innovative educational and scientific environment of the university; the operational block describes the two-component system of training of a Ph.D., where the educational component, along with the traditional-organized learning, includes project-organized learning, as well as additional learning outside the education process. Besides the obligatory work on the thesis research, the scientific component includes other forms and methods of the research and innovation activity at the university as a component of quasi-professional activity of future Ph.Ds. containing measures for the professional development of young scientists. The diagnostic block, which reflects the analytical and productive stage of the research, outlines the criteria, indicators and levels of readiness of the future Ph.D. for the research and innovation activity, outlining methods and tools for their determination. The result of the considered model is the disposition of future Ph.Ds. for the research and innovation activity. A further prospect of the research consists in its testing and experimental verification.

Keywords: doctor of philosophy, research and innovation activity, conceptual model, postgraduate student, professional training, higher education

В умовах розбудови «суспільства знань» в усьому світі суттєво підвищився соціальний запит на підготовку фахівців високоінтелектуальної праці, що призвело до масовізації вищої освіти, у т. ч. іiі докторського рівня. У Європейському просторі вищої освіти (ЄПВО) наразі велика увага приділяється вдосконаленню підготовки докторів філософії (ДФ) - Ph.D, що пов'язано $з$ політикою Європейського Союзу, яка спрямована на побудову найсильнішої економіки у світі, і тому акцентує свою увагу на забезпеченні якості підготовки Ph.D, які виступають ключовими гравцями (англ. key actors) у сфері виробництва знань, їх поширення i застосування [1, с. 12].

Основу нормативної бази підготовки ДФ в Європі становлять Стандарти і рекомендації щодо забезпечення якості вищої освіти (ESG), Європейська рамка кваліфікацій (EQF), документи Болонського процесу, зокрема Зальцбурзькі принципи-I та Зальцбурзькі принципиII, Принципи інноваційної докторантури тощо, які лягли в основу національних законодавчих баз європейських країн у сфері вищої освіти, а також слугували підставою до запровадження третього рівня вищої освіти в Україні, яка теж є членом ЄПВО. 
Модернізація вітчизняної системи формування наукових кадрів вимагає створення відповідної моделі процесу підготовки майбутніх ДФ до дослідницько-інноваційної діяльності (ДІД). Теоретичною основою побудови зазначеної моделі можуть слугувати наукові праці зарубіжних учених, в яких розкриваються різні аспекти докторського навчання. Зокрема, автори роботи [2] описують механізми інтеграції теорії і практики у дослідницькій підготовці ДФ в університеті Вісконсину у Медісоні (США); у роботі [3] мова йде про реалізацію практичних заходів щодо підготовки до ДІД філіппінських аспірантів. Цікавий досвід підготовки ДФ напрацьований у британському Мідлсекському університеті, в якому Ph.Dстуденти, навчаючись і одночасно працюючи на підприємствах, проводять дослідження у формі проєктів, що реалізуються у реальному виробничому середовищі. Така підготовка ДФ $є$ складовою процесу так званого навчання на робочому місці (англ. Work-Based Learning) [4]. Процес підготовки ДФ до ДІД в українській вищій школі не був предметом окремого дослідження.

Метою статті $є$ розробка концептуальної моделі підготовки майбутніх ДФ до ДІД. Запропонована модель складається 3 п’яти блоків (цільового, змістового, організаційного, операційного, діагностичного) та відображає три етапи організації цього процесу.

На теоретико-методологічному етапі, який представлений цільовим блоком, здійснювалась постановка мети експериментального дослідження, проводився аналіз вітчизняної нормативно-правової бази у сфері освіти, а також визначалися методологічні підходи та принципи організації процесу підготовки, що сформували його теоретикометодологічне підгрунтя. Мета дослідження полягала у формуванні готовності майбутніх ДФ до ДІД. Для досягнення поставленої мети було застосовано системний, синергетичний, діяльнісний, особистісно-орієнтований, компетентністний, проєктно-технологічний, акмеологічний, аксіологічний, андрагогічний, контекстний, соціокультурний, середовищний, індивідуально-творчий, рефлексивний наукові підходи, а також додержано деяких загальнодидактичних та специфічних принципів.

Метою другого, змістовно-практичного етапу процесу підготовки майбутніх ДФ до ДІД, $\epsilon$ реалізація комплексу педагогічних умов. Такими педагогічними умовами, як стверджує Л. Товажнянський, є: раціональний вибір змісту навчання відповідно до логіки науковотехнічного і соціального прогресу, що представлено у моделі змістовим блоком; створення інноваційного освітньо-наукового середовища (IOHC), структурні елементи якого склали основу організаційного блоку; використання прогресивних педагогічних технологій, що відображено в операційному блоці [7, с. 13].

Змістовий блок моделі розкриває зміст готовності майбутнього ДФ до ДІД. Його формування здійснювалось на підставі існуючих теоретичних підходів до розуміння професійної готовності майбутніх фахівців до науково-дослідницької та інноваційної діяльності; розробленому академічному профілі ДФ. Зазначений зміст готовності майбутніх ДФ до ДІД, структура якого складається 3 мотиваційно-вольового, особистісно-креативного, змістовноопераційного та рефлексивно-перспективного компонентів, відображений в освітньо-наукових програмах, навчальних планах, індивідуальних планах навчальної та наукової роботи аспірантів.

Важливою умовою для забезпечення ефективності підготовки ДФ $\epsilon$ створення відповідного ІОНС, що максимально стимулюватиме молодих науковців до розкриття їх творчого потенціалу та сприятиме активному залученню до процесів створення, впровадження та розповсюдження нових знань. Це й зумовило необхідність виокремлення у моделі підготовки організаційного блоку, в якому представлена структура IOHC, що складається із соціальної, інфраструктурної та інформаційно-комунікаційної підсистем, а також містить його завдання та функції (організаційну, ресурсну, навчально-методичну, комунікативну, мотивуючу, розвивальну, рефлексивну).

Розглянемо операційний блок моделі, що описує технологію процесу підготовки майбутніх ДФ до ДІД. Враховуючи дуальний характер цієї підготовки, яка містить освітню і наукову складову, запропонована система представлена двома компонентами: освітнім і науковим, що відображає реалізацію на практиці принципу «навчання через дослідження», який є засадничим у підготовці майбутніх фахівців дослідницько-інноваційного типу [5, с. 16]. Провідним чинником ефективного процесу підготовки ДФ, здатних до інноваційного мислення, самостійного здобуття і практичного застосування знань, є сучасні інноваційні технології 
навчання, насамперед проблемно-орієнтовані та проєктно-організовані, що спираються на проблемні, евристичні та дослідницькі загальнодидактичні методи і широко застосовують кооперативні форми організації навчання: роботу в парах, малих групах, командах.

Освітній компонент включає різні форми організації навчання: аудиторну та позааудиторну роботи, які дозволяють аспірантам отримати необхідні знання, уміння, навички для успішного здійснення майбутньої ДІД, а також розкрити інноваційний потенціал, оволодіти загальнопрофесійними компетентностями, передусім, вмінням генерувати ідеї, виявляти i аналізувати проблеми та визначати шляхи їх вирішення, комунікувати та працювати у команді, швидко знаходити потрібну інформацію та критично ії осмислювати.

Перший етап - це теоретична підготовка аспірантів, що пов'язана з вивченням основ ДІД, iï видів, форм, результатів, а також способів їх отримання; нормативно-правового забезпечення наукової та інноваційної діяльності в Україні, способів захисту інтелектуальної власності та шляхів комерціалізації результатів наукових досліджень; методів оформлення та оприлюднення результатів наукової роботи, підготовки проєктних заявок та договорів. Основу теоретичної підготовки аспірантів становлять спеціально розроблені комплекси дисциплін «Основи дослідницько-інноваційної діяльності», «Основи європейської проєктної діяльності», «Основи академічного письма та риторики», які включені до навчального плану підготовки здобувачів третього рівня вищої освіти.

Основними видами навчальної роботи є лекційні та практичні заняття, самостійна робота i контрольні заходи. Лекція як один 3 основних видів аудиторного навчання має на меті озброїти аспірантів фундаментальними знаннями, навчити вільно орієнтуватися в основних питаннях, практично значущих для майбутньої професійної ДІД; обгрунтувати шляхи і засоби теоретичного і практичного застосування отриманих знань. Для виконання поставленого завдання лекції повинні мати проблемний характер, відображати актуальні питання теорії i практики, залучати аспірантів до поглибленої самостійної роботи [6, с. 265].

Практичні заняття, під час яких відбувається перехід аспірантів на другий, практичний етап підготовки, проходять переважно у формі творчих майстерень - воркшопів і дозволяють їм набути особистого досвіду різних форм ДІД, реалізуючи принцип «навчання через дію». На таких занять майбутні ДФ критично аналізують наукові статті та автореферати дисертацій, проводять бенчмаркінг і розробляють структуру дисертаційної роботи, створюють шаблон файлу дисертації у WORD, здійснюють обгрунтований вибір журналу для публікації, опановують стандарт IMRAD для iї написання, готують тези виступу на конференціях та рецензії на опубліковані статті, пишуть есе, виступають з науковими повідомленнями і презентаціями, оформлюють проєкти документів на отримання об'єктів права інтелектуальної власності (ОПІВ), здійснюють підготовку аплікаційного пакету для участі у програмах академічної мобільності, розробляють ключові елементи проєктних заявок, у т. ч. для участі у міжнародних програмах Еразмус+ і Горизонт 2020, беруть участь у конкурсах та здійснюють експертизу розроблених проєктів тощо.

Як правило, ці заняття передбачають формат роботи в парах, що дає можливість здійснювати взаємооцінювання здобувачів, та у малих групах (4-5 осіб), діяльність яких може бути організована як кооперуюча або конкуруюча (метод конкурентних і кооперативних груп). Отже, під час таких занять розглядаються особливості різних форм ДІД та розробляється їх алгоритм, демонструються найкращі практики та аналізуються типові помилки, для чого широко застосовується кейс-метод, даються методичні рекомендації, відпрацьовуються професійні навички. Але доведення результатів практичної роботи аспірантів до кінцевого продукту (статті, проєкти тощо) потребує проведення великого обсягу самостійної роботи у позааудиторний час $\mathrm{i}$ вимагає від них творчого натхнення, вольових зусиль та високої самоорганізації.

3 метою формування у майбутніх ДФ цих та інших професійних й особистісних якостей доцільним є проведення таких додаткових заходів, як тренінги, рольові та організаційнодіяльнісні ігри, що проходять як у навчальний, так і позанавчальний час та передбачають широке використання інтерактивних та ігрових технологій, відрізняються професійною спрямованістю, мають сприятливий емоційний фон, активно використовують принцип співпраці та творчості, реалізуючись у груповій та командній організаційних формах. У процесі проведення практичних занять аспіранти здобувають навички самоорганізації, набувають досвіду колективної роботи у міждисциплінарних групах як у форматі кооперації, так i 
конкуренції, проводять само- і взаємооцінювання, проходять тестування, виконують вправи на саморефлексію та самоаналіз, здійснюють групову і колективну рефлексію.

Крім аудиторної і самостійної роботи аспірантів, в рамках навчальної дисципліни «Основи європейської проєктної діяльності» модель підготовки майбутніх ДФ до ДІД передбачає реалізацію проєктно-організованого навчання, що зумовлено необхідністю практично підготувати аспірантів до виконання дослідницьких та інноваційних проєктів у їхній майбутній професійній діяльності (змістовий аспект); сформувати проєктну компетентність як здатність використовувати проєктні технології для інноваційного перетворення дійсності у будь-якій сфері (технологічний аспект), а також розвинути загальнопрофесійні компетентності тих, хто навчається, за допомогою методу проєктів як одного 3 найбільш ефективних у педагогіці (дидактичний аспект). 3 огляду на вищевказане будемо розглядати включення майбутніх ДФ у розробку і виконання проєктів як основу їх практичної підготовки до ДІД.

Базові етапи проєктної діяльності становлять своєрідний цикл, який починається із занурення виконавців у реальну проблемну ситуацію, особистісного усвідомлення іiі значущості, а завершується вирішенням проблеми і представленням співтовариству отриманих результатів. Такий цикл може містити наступні етапи: підготовчий, ініціація та концептуалізація проєкту, фандрайзинг і розробка проєктної заявки, виконання проєкту, заключний етап.

Роботу над проєктом, яка передбачає самостійну та польову роботу за місцем його реалізації, здійснюють проєктні групи, що працюють під керівництвом консультанта над вирішенням обраної ними самостійно (після зустрічей, бесід, екскурсій, «круглих столів») проблеми університетського або регіонального масштабу, залучаючи за необхідності, додаткове фінансування за рахунок участі у конкурсах проєктів, у т. ч. спеціально організованих закладом із запрошенням спонсорів та потенційних замовників. Така діяльність, окрім іншого, підвищує самооцінку аспірантів, їх віру у власні сили, а отримані практичні результати надихають на нові ідеї та перемоги, підштовхують до подальшого розвитку та самовдосконалення, використовуючи також можливості неформальної освіти.

3 цією метою для аспірантів організовуються літні школи з кар'єрного розвитку молодих науковців, проводяться тренінги та воркшопи з актуальних академічних питань, зокрема щодо підготовки якісних презентацій, побудови ефективної публікаційної стратегії, створення і просування власного наукового бренду, розробки бізнес-стратегій тощо. Крім того, аспіранти залучаються до участі у вебінарах, онлайн конференціях, проходження масових онлайн курсів на платформах Prometeus, Coursera, участі у PhD-марафонах від SSLab та ін.

Підсумовуючи сказане, перерахуємо основні методи навчання, які застосовуються при реалізації освітнього компонента системи підготовки майбутніх ДФ до ДІД, згрупувавши їх для зручності у чотири групи, кожна 3 яких орієнтована на формування одного 3 компонентів готовності: 1) мотиваційно-стимулюючі: проблемне викладання, візуалізація, особистий вибір, екскурсії, бесіди, «круглі столи», (відео)конференції, презентації, конкурси; 2) розвитку креативності: «мозковий штурм», синектика, «світове кафе», асоціації, фокальні об'єкти, евристичні запитання, інтелектуальні карти (Mind-mapping) «шість капелюхів мислення», «три стільці» Уолта Діснея, квота Едісона, творче есе; 3) формування дослідницько-інноваційних та загальнопрофесійних умінь: засідання експертних груп; кейс-стаді, тренінги, воркшопи, рольові та організаційно-діяльнісні ігри, розробка і реалізація проєкту, публічні виступи; розробка проєктів статей, аплікаційних форм проєктних заявок, документів на ОПІВ, договорів на виконання НДР тощо; 4) рефлексивні: само- і взаємооцінювання, тестування, вправи на саморефлексію та самоаналіз, групова і колективна рефлексія.

Зазначимо, що наведена класифікація $є$ певною мірою умовною, оскільки більшість методів стосується формування одразу кількох компонентів готовності.

До засобів навчання відносимо: професійний досвід викладачів, НМКД, Moodle, спеціалізовану аудиторію, комп'ютерну техніку, програмне та мультимедійне забезпечення, інформаційні та літературні джерела, канцелярські предмети, засоби зв’язку (телефон, меседжери, соціальні мережі, е-пошта, форум тощо).

Третій етап підготовки майбутнього ДФ до ДІД - квазіпрофесійна діяльність представлений у системі науковим компонентом, який включає в себе три складові: самостійна робота над дисертаційним дослідженням, залучення аспірантів до різних форм ДІД, що реалізується в реальних умовах IOHC університету як потенційного місця їх майбутньої 
професійної діяльності, а також заходи, спрямовані на професійний розвиток майбутніх науковців. У зазначених видах діяльності можуть використовуватися такі організаційні форми: індивідуальні, парні (консультації), групові, колективні.

Серед умов, що сприяють ефективній роботі аспірантів над власним дисертаційним дослідженням, виділяємо: стратегію відбору претендентів на навчання, формалізацію вимог до наукового керівника із конкретним переліком його обов'язків, розробку індивідуального плану наукової роботи, систематичний моніторинг і контроль за його виконанням з боку наукового керівника та адміністрації університету.

Під час роботи над дисертацією використовуються такі форми організації як самостійна робота (за комп’ютером, у науковій бібліотеці чи архіві, науковій лабораторії), польова робота на базі дослідження, консультації з науковим керівником та іншими науковцями, аспірантами. При цьому формування готовності майбутнього ДФ до ДІД відбувається за допомогою таких методів: 1) мотиваційно-стимулюючі: особистий приклад наукового керівника та інших науковців, відвідування захистів дисертацій, участь та виступи на Ph.D-колоквіумах і наукових семінарах; 2) розвитку_креативності: вибір теми та методів дисертаційного дослідження, отримання оригінальних наукових результатів (розробка теорій, методів, способів, технологій, програм, проєктів нормативних документів тощо); 3) формування дослідницько-інноваційних умінь: проєктування та планування (розробка індивідуального плану наукової роботи, дослідницької пропозиції, змісту дисертації), самостійне проведення теоретичних та експериментальних досліджень у рамках дисертаційного проєкту, презентація та захист його результатів; 4) рефлексивні: самоорганізація та самоменеджмент, самоконтроль за виконанням індивідуального плану наукової роботи.

Паралельно з написанням дисертації аспіранти активно залучаються до інших форм ДІД в університеті як іiі повноцінні суб'єкти, а саме: дослідницької діяльності в рамках функціонуючих проєктних груп; керівної діяльності проєктами молодих учених та студентськими науковими проблемними групами; науково-організаційної діяльності в рамках наукового товариства студентів та аспірантів; наставницької діяльності над аспірантами молодших курсів; комунікативної діяльності у науковому середовищі (участь у публічних заходах, професійних співтовариствах і групах у соціальних мережах, оприлюднення результатів наукових досліджень, створення персональних профілів і блогів, розширення бази особистих контактів тощо).

Серед методів, що забезпечують формування готовності майбутнього ДФ до ДІД шляхом участі у зазначених формах діяльності можемо виділити такі: 1) мотиваційно-стимулюючі: перейняття традицій наукової школи (зустрічі, семінари-практики), особистий приклад науковців та реклама їх досягнень, відвідування публічних лекцій відомих учених; рейтингування за результатами діяльності; моральне та матеріальне заохочення; 2) розвитку креативності: пошук оригінальних ідей, участь у конкурсах на отримання грантів для реалізації дослідницьких та інноваційних проєктів; 3) формування дослідницько-інноваційних та загальнопрофесійних умінь: дослідницьке асистенство (англ. Research assistantships) [3, c. 175176] (робота у проєктних групах щодо розробки та/або реалізації дослідницьких та інноваційних проєктів), керівництво проєктами молодих учених та студентськими науковими роботами, участь у тематичних та міждисциплінарних наукових семінарах (вебінарах), «круглих столах», виступи на конференціях, участь у програмах академічної мобільності (стажування), публікація результатів у збірниках матеріалів конференцій, наукових журналах, монографіях, подання заявок на ОПІВ, виконання НДР на замовлення зовнішніх організацій, дослідницьке консультування аспірантів молодших курсів (англ. Research advising) [2, с. 360].

Важливою складовою успішної професійної діяльності майбутнього ДФ вважаємо його постійний професійний розвиток, прагнення самовдосконалення і самореалізації, формування позитивної «Я-концепції», що може бути забезпечено за допомогою таких методів: рефлексивні: самоаналіз, саморефлексія, SMART-аналіз постановки цілей, SWOT- аналіз, індивідуальний план професійного розвитку, публікаційна стратегія; мотиваційно-стимулюючі та розвитку креативності: формування власного наукового бренду (індекс цитування, персональні профілі, блоги), портфоліо.

До форм організації такої діяльності відносимо самоорганізацію, консультації з науковим керівником та іншими науковцями, аспірантами. Серед засобів, що забезпечують реалізацію наукового компоненту операційного блоку моделі, виділяємо такі: професійний досвід 
наукового керівника і членів дослідницького колективу, традиції наукової школи, науковий доробок зарубіжних і вітчизняних учених, принципи і методи наукового дослідження, науковий експеримент, інформаційні та літературні джерела, науковометричні та патентні бази, пошукові сервіси, наукове обладнання i витратні матеріали, комп'ютерна техніка, програмне та мультимедійне забезпечення, канцелярські предмети, засоби комунікації (телефон, меседжери, соціальні мережі, е-пошта, форум), персональні профілі і блоги науковців, мережа особистих контактів, додаткова фінансова підтримка (гранти, замовники наукової продукції).

Аналітико-результативний етап підготовки майбутніх ДФ до ДІД представлений у моделі діагностичним блоком, який включає критерії, показники та рівні готовності майбутнього ДФ до ДІД, а також методику оцінювання рівнів ії сформованості за допомогою стандартизованого та авторського діагностичного інструментарію. Результатом запропонованої моделі $\epsilon$ сформована у процесі навчання в аспірантурі готовність майбутнього ДФ до ДІД.

Отже, у статті розроблено концептуальну модель підготовки майбутнього ДФ до ДІД, що $\epsilon$ основою для реалізації відповідної педагогічної технології цього процесу як складової професійної підготовки здобувачів третього рівня вищої освіти.

Перспективами подальших досліджень $\epsilon$ апробація запропонованої моделі та іiі експериментальна перевірка.

\section{ЛITEPATУРA}

1. Auriol, L., Schaaper, M., \& Felix, B. Mapping careers and mobility of doctorate holders: Draft guidelines, model questionnaire and indicators. 2012. OECDiLibrary. DOI: 10.1787/5k4dnq2h4n5c-en

2. Byars-Winston A., Gutierrez B., Topp S., Carnes M. Integrating Theory and Practice to Increase Scientific Workforce Diversity: A Framework for Career Development in Graduate Research Training. CBE—Life Sciences Education. 2011. Vol. 10. No. 4. P. 357-367. DOI: 10.1187/cbe.10-12-0145.

3. Calma A. The Context of Research Training in the Philippines: Some Key Areas and Their Implications. Asia-Pacific Education Researcher. 2009. Vol. 18. No. 2. P. 167-184. DOI: 10.3860/taper.v18i2.1321.

4. Carol C., Abukari A. The impact of work-based research projects at postgraduate level. Journal of Work-Applied Management. 2015. Vol. 7. № 1. P. 3-14. DOI: 10.1108/JWAM-10-2015-006

5. Луговий В. І. Вища освіта через дослідження: концептуальні засади здійснення й оцінювання / В. І. Луговий, Ж. В. Таланова // Вища освіта України: Тематичний випуск «Педагогіка вищої школи: методологія, теорія, технології». - 2012. - Т. 1. - № 3. - С. 16-28.

6. Стрельніков В. Ю. Сучасні технології навчання у вищій школі / В. Ю. Стрельніков, І. Г. Брітченко. - Полтава: ПУЕТ, 2013. - 309 с.

7. Товажнянський Л. Л. Болонський процес i підготовка гуманітарно-технічної еліти /Л. Л. Товажнянський // Теорія і практика управління соціальними системами. - 2004. - № 2. - С. 11-18.

\section{REFERENCES}

1. Auriol L., Schaaper M., \& Felix B. Mapping careers and mobility of doctorate holders: Draft guidelines, model questionnaire and indicators. OECDiLibrary, 2012. doi: 10.1787/5k4dnq2h4n5c-en.

2. Byars-Winston A., Gutierrez B., Topp S., Carnes M. Integrating Theory and Practice to Increase Scientific Workforce Diversity: A Framework for Career Development in Graduate Research Training. CBE-Life Sciences Education, 2011, Vol. 10, no. 4, pp. 357-367. doi: 10.1187/cbe.10-12-0145.

3. Calma A. The Context of Research Training in the Philippines: Some Key Areas and Their Implications. Asia-Pacific Education Researcher, 2009, Vol. 18. no. 2, pp. 167-184. doi: 10.3860/taper.v18i2.1321.

4. Carol C., Abukari A. The impact of work-based research projects at postgraduate level. Journal of WorkApplied Management. 2015, Vol. 7. no. 1, pp. 3-14. DOI: 10.1108/JWAM-10-2015-006.

5. Luhovyi V. I., Talanova Zh. V. Vyshcha osvita cherez doslidzhennia: kontseptualni zasady zdiisnennia y otsiniuvannia [Higher education through research: conceptual foundations for implementation and evaluation]. Vyshcha osvita Ukrainy: Tematychnyi vypusk «Pedahohika vyshchoi shkoly: metodolohiia, teoriia, tekhnolohii», 2012, Vol. 1, no 3, pp. 16-28.

6. Strelnikov V. Yu., Britchenko I. H. Suchasni tekhnolohii navchannia u vyshchii shkoli [Modern technologies of education in high school]. Poltava, ПУЕT Publ., 2013, 309 p. (in Ukrainian)

7. Tovazhnianskyi L. L. Bolonskyi protses i pidhotovka humanitarno-tekhnichnoi elity [Bologna process and training of humanitarian and technical elite]. Teoriia i praktyka upravlinnia sotsialnymy systemamy, 2004, Vol. 2, pp. 11-18. 